\title{
Genetic Relationships Among Wild Lens Mill. Species Revealed by SDS -PAGE
}

\author{
Galina Suvorova $\cdot$ Nadezhda Kornienko
}

received / primljeno: 17.11.2010. accepted / prihvaćeno: 30.11.2010.

(C) 2011 IFVC

\begin{abstract}
Summary: Seed storage proteins of 18 lentil accessions of the following Lens taxa: L. culinaris, L. orientalis, L. odemensis, L. nigricans, L. ervoides, L. lamottei, L. tomentosus and L. lenticula, were analyzed by sodium dodecyl sulfate polyacrilamide gel electrophoresis (SDS-PAGE). All visible polypeptide bands were scored for presence or absence and data were used for dendrogram construction by UPGMA method. Three clusters were formed at the dendrogram: the first one integrated accessions of $L$. orientalis and $L$. odemensis; the second cluster joined L. culinaris и L. tomentosus accessions, and related to them L. lamottei species, the third cluster included L. nigricans and L. ervoides accessions. Species affiliation of accessions L. orientalis $\kappa-2861, L$. nigricans $\kappa-2859$ and L. nigricans $\kappa-2860$ was confirmed. Taxonomic position of $L$. lenticula $\mathrm{k}-2858$ accession was not determined exactly.
\end{abstract}

Key words: lentil, SDS-PAGE, seed storage protein, wild species

\section{Introduction}

Lentil, as an important legume crop, needs further improvement in order to increase plant productivity, disease resistance and adaptability to machinery cultivation. Wild lentil species can serve as an additional source of genetic diversity for creation of new lentil cultivars.

Taxonomy of genus Lens Mill. is still a topic open to discussions. The classification suggested by Barulina (1930) includes 5 species, where one cultivated species is Lens esculenta Moench. (a synonym is $L$. culinaris Medik) and four are wild species L. lenticula (Schreb) Alef., L. nigricans (M.B.) Godr., L. kotschyana (Boiss) Alef., L. orientalis (Boiss) Hand.-Mazz.

Czefranova (1971) made a critical study of Lens species and suggested the system including 9 taxa: L. montbretii (Fish.et May.) Davis et Peltm, L. penduncularis (Nabel) Czefr., L. culinaris Medik., L. orientalis (Boiss) Schmalh., L. cyanea (Boiss. et Hohen.), L. nigricans (Bieb.) Webl et Berth., L. lamottei Czefr., L. ervoides (Brign) Grande, L. uniflora (Ten.) Schur. The species L. montbretii is a synonim of $L$. kotschyana species, and L. ervoides is the one for L. lenticula. As a result there was re-

G. Suvorova $(\bowtie) \cdot$ N. Kornienko

The All-Russia Research Institute of Legumes and Groat Crops, P/b

Streletskoye, 302502 Orel, Russia

e-mail: galina@vniizbk.ru established authors' priority for L. orientalis and L. nigricans, renamed and described L. lamottei, restored 2 species L. uniflora and L. cyanea.

Studying wild Lens species and making interspecific crossings, Ladizinsky (1984) suggested his own system of Lens genus. Due to an interspecific incompatibility and hybrid sterility, different Lens accessions were grouped in 2 botanic species: L. culinaris and L. nigricans. L. culinaris and contained 3 subspecies: ssp. culinaris, ssp. orientalis, ssp. odemensis, while L. nigricans included ssp. nigricans and ssp. ervoides. It deserves mentioning that ssp. odemensis was excluded by Ladizinsky from $L$. nigricans on the bases of morphological differences of stipules and incompatibility with other forms of $L$. nigricans.

Summing up 15 years of research in wild species collecting, studying and hybridization, Ladizinsky (1993) came to a conclusion that in Lens genus there should be isolated such species as L. culinaris ssp. culinaris, L. culinaris ssp. orientalis, L. odemensis, L. ervoides, L. nigricans. Taxon L. montbretii should be returned to Vicia genus as Vicia montbretii. This species is different not only morphologically, but in the number of chromosomes $(2 n=12)$ whereas the Lens genus chromosomes number is $2 n=14$.

\footnotetext{
Acknowledgements: The researchers were supported by the Ru-
} ssian Foundation for Basic Research (09-04-97516). 
Two more species were later added to Lens genus (Oss et al. 1997). The researches admitted L.lamottei Czefr. species identified by Czefranova (1971) in herbarium samples of L. nigricans. Some known populations of this species came from France, Spain, and Morocco. Ladizinsky isolated L. tomentosus Ladiz. species, that was known earlier as a $L$. orientalis variant and was different from the latter by its pubescent pods.

Though there was an opinion that $L$. tomentosus and $L$. odemensis should be reduced to sub-species of L. culinaris (Ferguson et al. 2000), data of molecular and cytological analysis (Galasso 2003, Sonnante et al. 2003, Duran 2004) confirmed isolation of $L$. lamottei and $L$. tomentosus to independent species.

So, most contemporary researches recognized the next seven taxa of genus Lens: L. culinaris Medik. (L. esculenta Moench.), L. orientalis (Boiss.) Hand.-Mazz., L. odemensis Ladiz., L. nigricans (M.B.) Godr., L. ervoides (Brign.) Grande, L. lamottei Czefr., L. tomentosus Ladiz. Only L. culinaris is a cultivated species, and all the rest are wild ones. In this study we used species definitions for Lens culinaris and Lens orientalis (Boiss.) Schmalh, accepted by Russian botanist Czefranova (1971).
The objective of this study was to establish phylogenetic relations between the species of genus Lens and to clarify systematic position of some lentil accessions on the base of seed storage proteins SDS-PAGE analysis.

\section{Materials and Methods}

Materials for research were 18 Lens accessions of different origins, covering all up to date known taxa (Tab. 1). Lentil accessions were obtained from N. I. Vavilov Research Institute of Plant Industry (VIR), where part of them that originally belong to VIR collection was marked with letter $\mathrm{k}$, and accessions firstly received from the International Center for Agricultural Research in the Dry Areas (ICARDA) retained their original code. Seed storage proteins were analyzed by sodium dodecyl sulfate polyacrylamide gel electrophoresis (SDSPAGE) in gel of $12.5 \%$ concentration (Konarev et al. 2000). Electrophoretic spectra were analyzed on the base of presence or absence of all visible protein bands. Dissimilarity value (1-F) was estimated according to Nei and Li (1978) and dendrogram was constructed by UPGMA method.

Table 1. List of lentil accessions used in SDS-PAGE analysis Tabela 1. Spisak akcesija sočiva korišćenih u SDS-PAGE analizi

\begin{tabular}{|c|c|c|c|}
\hline Number & Species & Accession name & Country of origin \\
\hline Broj & Vrsta & Naziv akcesije & Zemlja porekla \\
\hline 1 & L. orientalis & ILWL 7 & Turkey \\
\hline 2 & L. orientalis & ILWL 11 & Syria \\
\hline 3 & L. orientalis & $\mathrm{k}-2861$ & Syria \\
\hline 4 & L. lenticula & $\mathrm{k}-2858$ & Turkey \\
\hline 5 & L. tomentosus & ILWL 90 & Turkey \\
\hline 6 & L. tomentosus & ILWL 120 & Syria \\
\hline 7 & L. odemensis & ILWL 21 & Palestine \\
\hline 8 & L. odemensis & ILWL 164 & Syria \\
\hline 9 & L. lamottei & ILWL 29 & Spain \\
\hline 10 & L. lamottei & ILWL 428 & Spain \\
\hline 11 & L. ervoides & ILWL 43 & Croatia \\
\hline 12 & L. ervoides & ILWL 54 & Palestine \\
\hline 13 & L. nigricans & ILWL 30 & Spain \\
\hline 14 & L. nigricans & $\mathrm{k}-2859$ & Italy \\
\hline 15 & L. nigricans & $\mathrm{k}-2860$ & Turkey \\
\hline 16 & L. culinaris & Vekhovskaya & Russia \\
\hline 17 & L. culinaris & Obraztsov Chiflik 7 & Bulgaria \\
\hline 18 & L. culinaris & Svetlaya & Russia \\
\hline
\end{tabular}




\section{Results and Discussion}

The Electrophoregram revealed 75 polypeptide bands of different insensitivity; most of them were polymorphic (Fig. 1). The greatest protein diversity was observed in area of 30-65 kDa. Dendrogram, created on the base of seed storage protein electrophoretic spectra, showed that Lens species were quite different from each other and accessions of every species formed independent groups except of $L$ tomentosus samples (Fig. 2).

The intraspecific variation of lentil in seed storage protein spectra was significantly lower than the interspecific one. Nevertheless, high diversity was observed inside of $L$. orientalis, $L$.

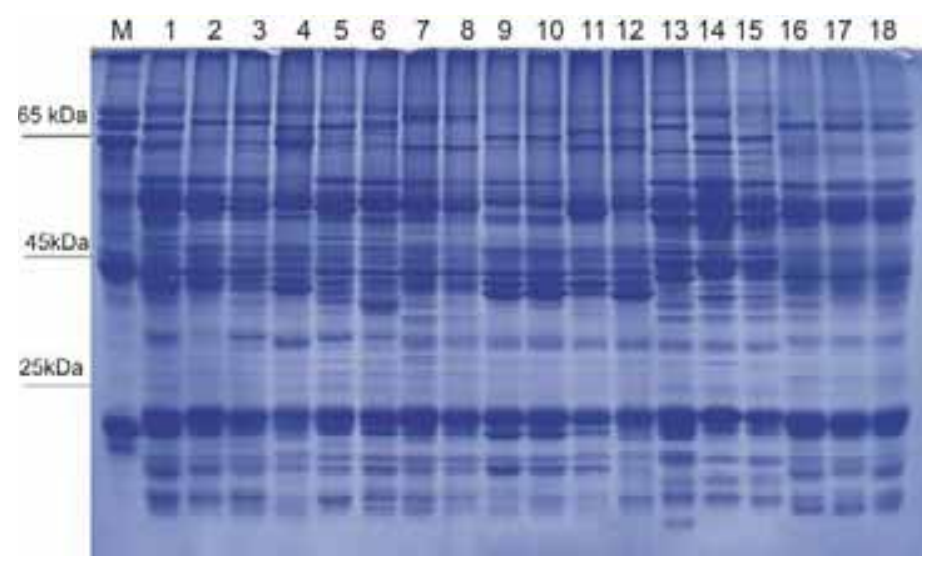

Figure 1. Protein profiles of Lens species generated by SDS-PAGE. M - marker of molecular weight (soybean protein). Lanes: 1, 2, 3 - L. orientalis; 4 - L lenticula; 5,6 - L tomentosus, 7,8 - L. odemensis, 9,10 - L. lamottei; 11,12 - L. ervoides, 13,14,15 - L. nigricans, 16,17,18 - L. culinaris (numeration corresponds to Table 1 )

Slika 1. Proteinski profili vrsta roda Lens species stvoreni pomoću SDS-PAGE. M - marker molekularne mase (protein soje). Trake: 1, 2, 3 - L. orientalis, 4 - L. lenticula; 5, 6 - L. tomentosus, 7, 8 - L odemensis, 9, 10 - L. lamottei; 11,12 - L. ervoides; 13, 14, 15 - L. nigricans, 16, 17, 18 - L. culinaris (brojevi odgovaraju onima u tabeli 1)

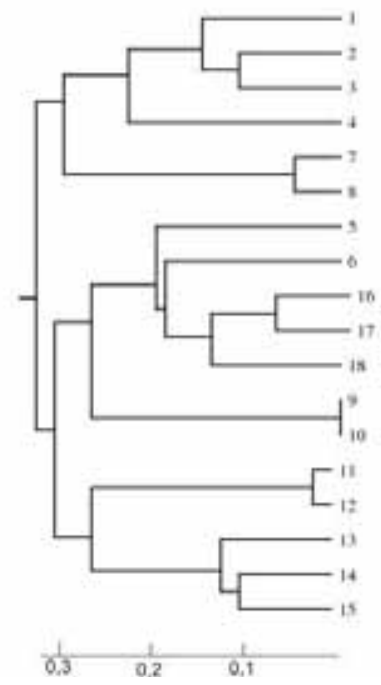

Figure 2. Dendrogram constructed on the base of Nei and Li distance. 1, 2, 3 - L. orientalis; $4-L$. lenticula; 5,6 - L. tomentosus; 7,8 - L. odemensis; 9,10 - L. lamottei; 11,12 - L. ervoides; 13,14,15 - L. nigricans; 16,17,18 - L. culinaris (numeration corresponds to Table 1)

Slika 2. Dendrogram konstruisan na osnovu udaljenosti Neija i Lija. 1, 2, 3 - L. orientalis; 4 - L. lenticula; 5, 6 - L. tomentosus; 7, 8 - L. odemensis; 9, 10 - L. lamottei; 11, 12 - L. ervoides; 13, 14, 15 - L. nigricans; 16, 17, 18 - L. culinaris (brojevi odgovaraju onima u tabeli 1 ) 
nigricans, $L$. culinaris species. The accessions of $L$. odemensis and $L$. ervoides were less distinguished and $L$. lamottei samples were characterized by absolutely identical spectra. It was interesting that $L$. orientalis $\mathrm{k}-2861$ accession from VIR collection was quite closely connected to $L$. orientalis ILWL11 accession from ICARDA, $L$. nigricans $\mathrm{k}-2859$ and $\mathrm{k}-2860$ accessions were close to each other and belonged to L. nigricans ILWL 30 group that proved their species affiliation. Accession k-2858 known as L. lenticula appeared to be in one group with $L$. orientalis, though not very close.

However, in spite of obvious relation of $L$. lenticula k-2858 accession to $L$. orientalis, at the moment there is no sound evidence to determine it as $L$. orientalis species. At the same time, those accessions were located at the dendrogram far enough from $L$. ervoides, species which was supposed to be a synonym of $L$. lenticula by Chefranova (1971). Dissimilarity value between к-2858 and L. ervoides accessions was high and means 0.723 and 0.745 . On the whole, L. lenticula was quite distant from all analyzed species and its dissimilarity coefficient between the nearest $L$. orientalis ILWL7 accession was also at high level (0.422). Therefore, the described situation did not clarify the systematic position of $L$. lenticula.

Presumably three clusters can be isolated on the dendrogram. The first cluster integrates accessions of $L$. orientalis and $L$. odemensis species. The second one joins $L$. culinaris and $L$. tomentosus accessions, and related to them $L$. lamottei species. The third cluster includes $L$. nigricans and $L$. ervoides species. According to electrophoretic spectra of seed storage proteins, it was revealed that $L$. orientalis appeared to be closely related to $L$. odemensis than to other species; $L$. culinaris was found to be closely relative to $L$. tomentosus; L. nigricans was supposed to be closely allied to L. ervoides. Though L. lamottei was grouped into one cluster with $L$. culinaris and $L$. tomentosus, dissimilarity value between $L$. lamottei and other species was not less than 0.522 .

SDS-PAGE analysis was applied for seed proteins of wild lentil relative by other researchers (Sammour 1994, Ahmad et al. 1997, Zimmniak-Przybylska et al. 2001). Studying five Lens taxa, Sammour (1994) and Ahmad et al. (1997) reached a conclusion that L. orientalis and L. odemensis appeared to be the wild progenitors of L. culinaris. A complete set of taxa including recently recognized $L$. tomentosus and $L$. lamottei was used by Zimmniak-Przybylska et al. (2001). As for relationships among studied taxa the most closely relative species were $L$. culinaris and $L$. odemensis from the one side, and L. orientalis and L. tomentosus from the other side.

Our results are to some extent in contradiction with the above mentioned regarding the nearest relatives of $L$. culinaris. This discrepancy among our result and data of Zimmniak-Przybylska (2001) revealed by the same method can be explained by different Lens accessions used in analysis.

In contrast, Duran \& Peres de la Vega (2004) using RAPD and ISSR markers found that three taxa L. culinaris, $L$. orientalis and $L$. tomentosus grouped into one cluster, with $L$. tomentosus being the closest species to cultivated lentil.

Applying multi-target fluorescence in situ hybridization (FISH) on seven Lens taxa I. Galasso (2003) concluded that the most similar karyotype to cultivated lentil was that of $L$. orientalis, whereas $L$. nigricans and $L$. tomentosus were two species that showed the most divergent FISH patterns. At the same time, Galasso suggested that two L. tomentosus accessions (ILWL 149 and ILWL 120) were probably misclassified based on the fact that their chromosome morphology and FISH karyotypes were more similar to L. culinaris than to L. tomentosus.

One of the $L$. tomentosus accessions used at the present study was ILWL 120. If the hypothesis of misclassification can be accepted, it explains the fact of close similarity among $L$. tomentosus and $L$. culinaris cultivars revealed in our experiment.

\section{Conclusions}

Having performed the SDS-PAGE analysis of lentil seed storage protein of 8 taxa of Lens genus, we ascertained genetic relations among the species and reached the conclusion that $L$. tomentosus ILWL 120 is the closest accession to cultivated lentil and confirmed specific affiliation of $L$. orientalis $\mathrm{k}-2861$ and $L$. nigricans $\mathrm{k}-2859$ and k-2860 samples of the collection of N. I. Vavilov Research Institute of Plant Industry. The obtained results can be useful in taxonomic definition of various accessions, interspecific hybridization and breeding programs. 


\section{References}

Ahmad M, Fautrier A G, Burritt D J, McNell D L (1997): Genetic diversity and genetic relationships in Lens species and their interspecific hybrids as determined by SDS-PAGE. New Zealand J. Crop Hort. Sci. 25: 99-108

Barulina E (1930): Chechevitsa SSSR i drugih stran. Nauka, Leningrad

Chefranova Z (1971): Obzor vidov roda Lens Mill. Novosti sistematiki vysshikh rastenii 8: 184-191

Duran Y, Peres de la Vega M (2004): Assessment of genetic variation and species relationships in a collection of Lens using RAPD and ISSR. Spanish J. Agric. Res. 2: 538-544

Ferguson M E, Maxted N, Van Slageren M, Robertson L D (2000): A re-assessment of the taxonomy of Lens Mill. (Leguminose, Papilionoideae, Vicieae). Bot. J. Linnean Society 133: 41-59
Galasso I (2003): Distribution of highly repeated DNA sequences in species of the genus Lens Mill. Genome 46: 11181124

Ladizinsky G (1993): Wild Lentils. Crit. Rev. Plant Sci. 12: 169184

Ladizinsky G, Braun D, Goshen D, Meuhlbauer F (1984): The biological species of the genus Lens L. Bot. Gaz. 145: 253261

Oss H, Aron Y, Ladizinsky G (1997): Chloroplast DNA variation and evolution in the genus Lens Mill. Theor. Appl. Genet. 94: 452-457

Sammour R H (1994): Species relationships in genus Lens as indicated by electrophoresis. Feders Repert. 105: 283-286

Sonante G, Galasso I, Pignone D (2003): ITS sequence analysis and phylogenetic inference in genus Lens Mill. Ann. Bot. 91: 49-54

Zimniak-Przybylska Z, Przybylska J, Krajewski P (2001): Electrophoretic seed globulin patterns and species relationships in the genus Lens Miller. J. Appl. Genet. 42: 435-447 


\title{
Genetički odnosi između samoniklih vrsta Lens Mill. otkriveni pomoću SDS -PAGE
}

\author{
Galina Suvorova $\cdot$ Nadežda Kornjijenko
}

Sveruski istraživački institut za mahunarke i strna žita, Arjol, Rusija

Izvod: Izvršena je elektroforeza natrijum-dodecil-sulfatnim poliakrilamidnim gelom (SDS-PAGE) rezervnih proteina semena 18 akcesija sledećih taksona roda Lens: L. culinaris, L. orientalis, L. odemensis, L. nigricans, L. ervoides, $L$. lamottei, L. tomentosus i L. lenticula. Ispitano je prisustvo svih vidljivih polipeptidnih traka, a podaci su poslužili za pravljenje dendrograma UPGMA metodom. Dendrogram su činila tri klastera: prvi sa združenim akcesijama $L$. orientalis i $L$. odemensis, drugi sa združenim akcesijama L. culinaris i L. tomentosus i njima srodnom vrstom L. lamottei $\mathrm{i}$ treći koji je uključio akcesije L. nigricans i L. ervoides. Bila je potvrđena srodnost akcesija L. orientalis k-2861, L. nigricans k-2859 i L. nigricans k-2860. Taksonomski položaj akcesije L. lenticula k-2858 nije bilo moguće precizno odrediti. Ključne reči: rezervni proteini semena, samonikle vrste, sočivo, SDS-PAGE 